\title{
Projected shifts in loggerhead sea turtle habitat in the Northwest Atlantic Ocean due to climate change
}

\section{Samir Patel ( $\nabla$ spatel@cfarm.org )}

Coonamessett Farm Foundation

\section{Megan Winton}

Atlantic White Shark Conservancy

Joshua Hatch

Northeast Fisheries Science Center

Heather Haas

Northeast Fisheries Science Center

Vincent Saba

Northeast Fisheries Science Center

\section{Gavin Fay}

University of Massachusetts Dartmouth

Ronald Smolowitz

Coonamessett Farm Foundation

\section{Research Article}

Keywords: Sea Surface Temperature, Depth, Foraging, Satellite Telemetry, Middle Atlantic 27 Bight, Southern New England, Georges Bank, Gulf of Maine

Posted Date: January 8th, 2021

DOI: https://doi.org/10.21203/rs.3.rs-135577/v1

License: (c) (1) This work is licensed under a Creative Commons Attribution 4.0 International License. Read Full License

Version of Record: A version of this preprint was published at Scientific Reports on April 23rd, 2021. See the published version at https://doi.org/10.1038/s41598-021-88290-9. 
1 Projected shifts in loggerhead sea turtle habitat in the Northwest Atlantic Ocean due to

2 climate change

4 Samir H. Patel*1, Megan V. Winton ${ }^{2,3}$, Joshua M. Hatch ${ }^{4}$, Heather L. Haas ${ }^{4}$, Vincent S. Saba ${ }^{5}$,

5 Gavin Fay ${ }^{2}$, Ronald J. Smolowitz ${ }^{1}$

$7 \quad *$ Corresponding Author

$8{ }^{1}$ Coonamessett Farm Foundation, 277 Hatchville Road East Falmouth, MA 02536 USA.

$9 \quad{ }^{2}$ University of Massachusetts Dartmouth, School for Marine Science and Technology $836 \mathrm{~S}$

10 Rodney French Blvd, New Bedford, MA 02744 USA.

$11{ }^{3}$ Atlantic White Shark Conservancy, 235 Orleans Road, North Chatham, MA, USA 02650

$12{ }^{4}$ Northeast Fisheries Science Center, National Marine Fisheries Service, National Oceanic and

13 Atmospheric Administration, 166 Water Street Woods Hole, MA 02543 USA.

$14{ }^{5}$ Geophysical Fluid Dynamics Laboratory, Northeast Fisheries Science Center, National Marine

15 Fisheries Service, National Oceanic and Atmospheric Administration, Princeton University

16 Forrestal Campus, 201 Forrestal Road Princeton, NJ, 08544 USA.

18 Contact Information:

19 S. Patel: spatel@cfarm.org

20 M. Winton: megan.winton@gmail.com

21 J. Hatch: joshua.hatch@noaa.gov

22 H. Haas: heather.haas@noaa.gov

23 V. Saba: vincent.saba@noaa.gov

24 G. Fay: gfay@umassd.edu

25 R. Smolowitz: rjsmolowitz@ cfarm.org

27 Keywords: Sea Surface Temperature, Depth, Foraging, Satellite Telemetry, Middle Atlantic

28 Bight, Southern New England, Georges Bank, Gulf of Maine 


\section{Abstract}

It is well established that sea turtles are vulnerable to atmospheric and oceanographic

34 shifts associated with climate change. However, few studies have formally projected how their

35 seasonal marine habitat may shift in response to warming ocean temperatures. Here we used a

36 high-resolution global climate model and a large satellite tagging dataset to project changes in

37 the future distribution of suitable thermal habitat for loggerheads along the northeastern

38 continental shelf of the United States. Between 2009 and 2018, we deployed 196 satellite tags on

39 loggerheads within the Middle Atlantic Bight (MAB) of the Northwest Atlantic continental shelf

40 region, a seasonal foraging area. Tag location data combined with depth and remotely sensed sea

41 surface temperature (SST) were used to characterize the species' current thermal range in the

42 MAB. The best-fitting model indicated that the habitat envelope for tagged loggerheads

43 consisted of SST ranging from $11.0^{\circ}-29.7^{\circ} \mathrm{C}$ and depths between $0-105.0 \mathrm{~m}$. The calculated

44 core habitat consisted of temperatures between $15.0^{\circ}-28.0^{\circ} \mathrm{C}$ and at depths between $8.0-92.0$

$45 \mathrm{~m}$ and the highest probability of presence occurred in regions with SST between $17.7^{\circ}-25.3^{\circ} \mathrm{C}$

46 and at depths between $26.1-74.2 \mathrm{~m}$. The habitat suitability model was then forced by a high-

47 resolution global climate model under a doubling of atmospheric $\mathrm{CO}_{2}$ to project loggerhead

48 probability of presence over the next 80 years. Our results suggest that loggerhead thermal

49 habitat and seasonal duration will likely increase in northern regions of the NW Atlantic shelf.

50 This change in spatiotemporal range for sea turtles in a region of high anthropogenic use may

51 prompt adjustments to the localized protected species conservation measures.

\section{Introduction}

Warming ocean temperatures due to climate change are already having a measurable

54 impact on ecological processes (IPCC 2014). An emerging body of research has documented 
55 distribution shifts (Pinsky et al. 2020), phenological changes to seasonal migration and

56 reproduction (Poloczanksa et al. 2013), and trophic mismatch (Edwards and Richardson 2004) in

57 a wide variety of marine taxa. All of these changes increase the difficulty to manage

58 commercially valuable marine species (Weatherdon et al. 2016) and protect endangered and

59 threatened animals (Mawdsley et al. 2009).

60 Understanding species distribution and habitat preferences is becoming a fundamental

61 component to developing effective resource management and conservation strategies (Cañadas

62 and Hammond 2008, Franco et al. 2004). Fisheries bycatch is one of the most serious threats to

63 sea turtles around the world (Spotila et al. 2000, Wallace et al. 2013). Attempts to mitigate

64 bycatch levels are often based on an understanding of when and where a species occurs over time

65 and how interactions occur with the fishing gear (Dunn et al. 2011, Senko et al. 2014). With the

66 advent of time/area closures in fisheries management, more research is being conducted to

67 understand the spatio-temporal nature of by-catch species (Dunn et al. 2011). In the Pacific,

68 fisheries interactions with loggerhead sea turtles (Caretta caretta) have resulted in temporary

69 area closures, and vessels must comply with stringent regulations to prevent the incidental

70 capture of this species (Howell et al. 2008). While these types of regulations have resulted in

71 reduced bycatch of both loggerhead and leatherback sea turtles (Dermochelys coriacea)

72 (Swimmer et al. 2017), they will need to be continuously modified to account for climate change.

73 Sea turtles, including the loggerhead, are susceptible to climate and ecosystem changes,

74 particularly those associated with temperature. This is most commonly documented with regards

75 to sea turtle reproductive biology such that nesting phenology, hatchling sex ratios, and various

76 metrics of nesting success can all be affected by slight changes $\left(<3^{\circ} \mathrm{C}\right)$ in ocean and air

77 temperature (e.g. Saba et al, 2012, Santidrián Tomillo et al. 2015, Patel et al. 2016a). In terms of 
marine distribution, habitable temperature ranges are broad, with loggerhead sea turtles observed throughout the NW Atlantic shelf region in waters with sea surface temperature (SST) ranging from $7^{\circ}-30^{\circ} \mathrm{C}$ (Shoop and Kenney 1992). In a smaller study on loggerheads at the southern edge of the NW Atlantic shelf region, Coles and Musick (2000) found that the available thermal range $\left(4.9^{\circ}-32.2^{\circ} \mathrm{C}\right)$ was larger than the occupied range $\left(13.3^{\circ}-28.0^{\circ} \mathrm{C}\right)$, indicating that loggerheads at-sea likely stay within a preferred temperature envelope. Many marine species within the region are expected to shift their distribution to remain in preferred thermal habitat (Kleisner et al. 2017). We hypothesize that loggerheads will do so similarly as the climate warms.

In the marine realm, animal distribution modelling has been limited by the availability of species occurrence data and relevant environmental data (Tyberghein et al 2012). Satellite telemetry has been occurring for over 35 years (Stoneburner 1982). However, due to the cost prohibitive nature of these technologies, it is rare for a single population to be studied over many consecutive years (Hart and Hyrenbach 2009, Hebblewhite and Haydon 2010, Hays and Hawkes 2018). As a result, developing correlations between sea turtle marine habitat and oceanographic variables have been limited to short term telemetry studies or dependent on opportunistic data sources, like fisheries bycatch (e.g. Hawkes et al. 2007, Howell et al. 2008, Swimmer et al. 2017). The increasing abundance and availability of information collected by remote sensing tools such as satellite relayed data loggers and long-term high-resolution environmental data means that animal distribution models can now more easily be compared with oceanographic variables (Hazen et al. 2013, Roe et al. 2014, Winton et al 2018).

Projections from global climate models are regularly used to estimate long-term shifts in the distribution of marine species (Poloczanska et a. 2013). However, only a few studies have 
101 attempted to project, over a long-term, the climate change induced shift in available marine

102 habitat for sea turtles. Using a thermal range previously established by Hawkes et al. (2007) for

103 loggerheads in the NW Atlantic, Witt et al. (2010) projected the change in available thermal

104 habitat in the Atlantic through 2089 using the global climate model HadGEM1 (Hadley Centre

105 Global Environmental Model, version 1). Witt et al. (2010) calculated annualized northern and

106 southern extents at which $90 \%$ of SST in the Atlantic Ocean will remain above $15^{\circ} \mathrm{C}$ as a

107 threshold for loggerhead distribution. In the Pacific, Hazen et al. (2013) used a generalized

108 additive model to estimate the relationships between sea turtle distribution and several

109 oceanographic variables. SST and chlorophyll-a values from Earth system model GFDL ESM

1102.1 (Geophysical Fluid Dynamics Lab Earth System Model 2.1) were used to project the

111 potential change in available ocean habitat through 2100 (Hazen et al. 2013). This bioclimatic

112 envelope model provided a more direct correlation between the species' distribution and the

113 projected available habitat (Araujo and Townsend Peterson 2012).

114 The Middle Atlantic Bight (MAB), Southern New England (SNE), Georges Bank (GB),

115 and the Gulf of Maine (GOM) are adjacent continental shelf regions of the NW Atlantic Ocean

116 (Figure 1) that support a number of large commercial fisheries, a high amount of commercial

117 and recreational vessel traffic, and the majority of the United States (US) federal wind energy

118 lease areas (Gilman et al. 2016). Based on aerial surveys, the MAB is also a seasonal foraging

119 ground for $\sim 40,000-\sim 60,000$ juvenile and adult loggerheads. The South Atlantic Bight (SAB)

120 region of the US, between North Carolina and central Florida, is home to 500,000 - 1,000,000

121 loggerheads during the summer months (NEFSC and SEFSC 2011). The population values for

122 the MAB may be an underestimate as stable isotope analysis and satellite telemetry data indicate 
123 that potentially $30-50 \%$ of loggerheads that nest and reside along the US eastern seaboard

124 seasonally forage within the MAB (Griffin et al. 2013, Ceriani et al. 2017, Winton et al 2018).

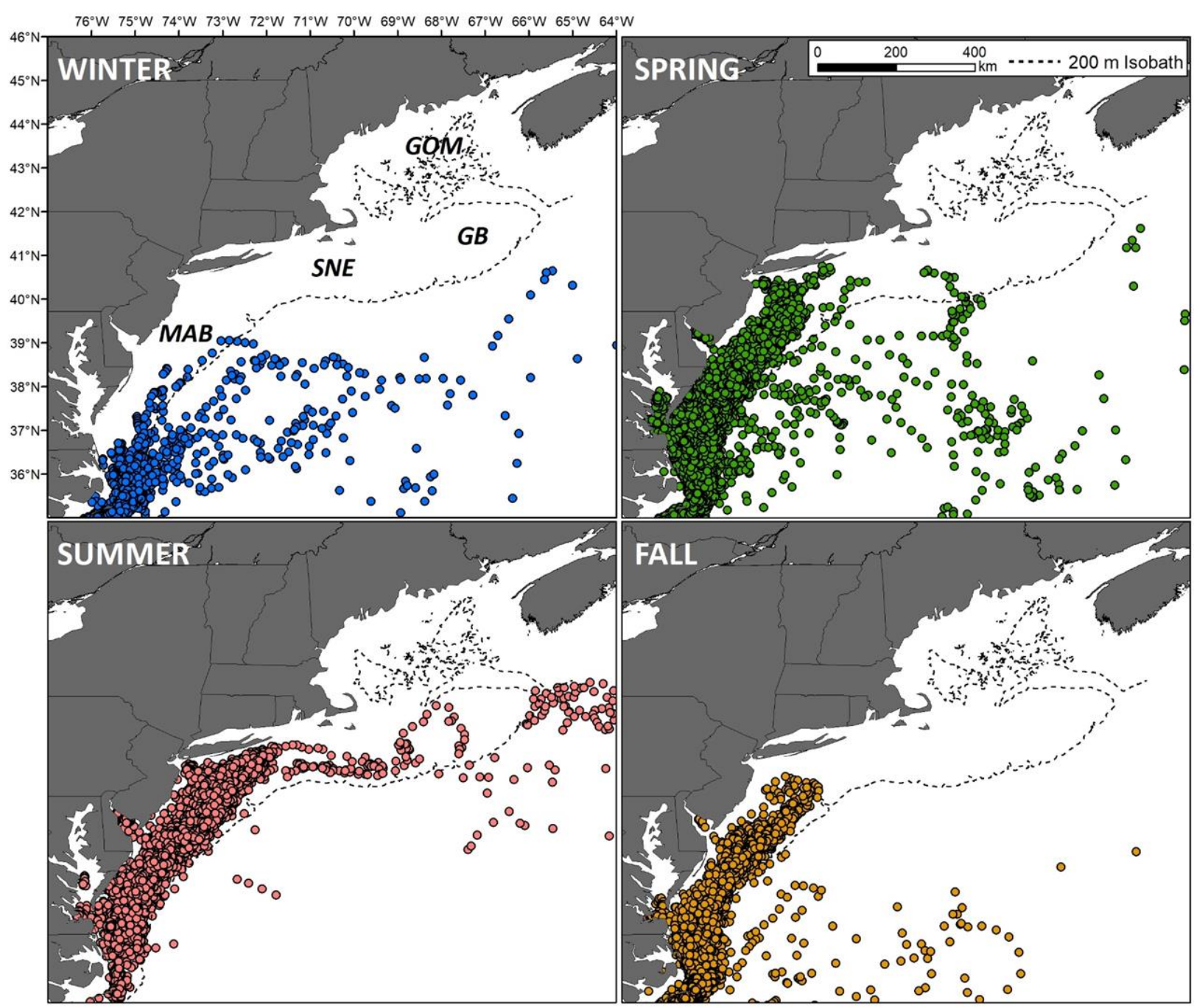

Figure 1: Reconstructed tracks from 196 loggerhead sea turtles satellite tagged between 2009 - 2018 within the northwest Atlantic. Dashed lines denote the $200 \mathrm{~m}$ bathymetric contour. GOM = Gulf of Maine, GB = Georges Bank, SNE = Southern New England, and $\mathrm{MAB}=$ Middle Atlantic Bight.

We calculated the probability of turtle presence in the NW Atlantic shelf region based on

126 loggerhead distribution data collected from 2009-2018 and the observed relationships with SST

127 and depth. We projected the changes to loggerhead bathythermal habitat over the next 80-years

128 of climate change using projections of SST for the region from a high-resolution global climate

129 model. Overall, we suggest that the loggerhead marine bathythermal habitat will likely expand to 
130 the northern regions and increase in seasonal duration to earlier in the spring and later into the

131 fall.

132 Methods

133 Loggerhead Satellite Tagging

134 All loggerheads were tagged between $2009-2018$. The majority of turtles $(\mathrm{n}=190)$ were

135 tagged within the MAB between May and September. Two turtles were tagged in eastern GB and

136 one was tagged off-shelf near southern MAB at the edge of the Gulf Stream, a fast moving

137 current that flows along the US eastern seaboard pulling warm water from the Gulf of Mexico

138 northward and eastward (Fofonoff 1981). Three additional turtles were tagged off of the North

139 Carolina coast in February. Curved carapace length, from anterior notch to posterior tip, was

140 measured for each captured turtle. Most $(n=186)$ turtles were equipped with a satellite relay

141 data logger manufactured by the Sea Mammal Research Unit at the University of St Andrews;

142 and ten turtles were equipped with a Wildlife Computers SPOT tag. See Patel et al. (2016b,

143 2018), Winton et al. (2018) and Crowe et al. (2020) for full details on capture and handling

144 protocols, satellite tag parameterizations, and more details from the satellite tag data.

145 All fieldwork was approved by the US National Marine Fisheries Service (NMFS)

146 Atlantic Institutional Animal Care and Use Committee and the US Endangered Species Act

147 (ESA) Section 10(a)(1)(a). Work was conducted under ESA permits \#14249 and \#18526 issued

148 to Coonamessett Farm Foundation, Inc., ESA permits \#1576 and \#16556 issued to the Northeast

149 Fisheries Science Center and ESA permit \#1551 issued to the Southeast Fisheries Science

150 Center. All methods were carried out in accordance with approved guidelines and regulations.

151 Data Processing 
Telemetered location data were processed following standard guidelines for sea turtle

153 tracking data. Tracks of individual turtles were filtered using a Continuous Time Correlated

154 Random Walk movement model fitted to location data using the software 'Template Model

155 Builder' (Kristensen et al. 2016) in R (R Core Team 2017). Daily position estimates were

156 interpolated from each movement model's output (Johnson et al. 2008; Albertsen et al. 2015;

157 Winton et al. 2018) to correct for the different transmission rates of each tag and to reduce

158 autocorrelation in position estimates. Prior to fitting the movement model, all location

159 coordinates were re-projected into the oblique Mercator center projection centered on $35.0^{\circ} \mathrm{N}$,

$16075.0^{\circ} \mathrm{W}$ using R package 'rgdal' (Bivand et al. 2015) and a speed filter with a max speed of 5

$161 \mathrm{~km} / \mathrm{hr}$ was applied to remove errant telemetered locations (TEWG 2009).

162 For analysis, loggerhead locations were aggregated over the NMFS Atlantic Marine

163 Assessment Program for Protected Species (AMAPPS) spatial grid that has a 10-km resolution

164 (Winton et al. 2018). For model fitting, we used loggerhead location estimates from continental

165 shelf waters (depths $<200 \mathrm{~m}$ ) between $33.5^{\circ} \mathrm{N}-41.6^{\circ} \mathrm{N}$, which encompasses the MAB as

166 delineated by NMFS statistical areas (Clay 1996) and corresponds to the highest density area

167 traversed by satellite-tagged loggerheads (Winton et al. 2018). Although on occasion

168 loggerheads were tracked in waters deeper than $200 \mathrm{~m}$ and north of $41.6^{\circ} \mathrm{N}$ latitude, those

169 locations were removed from this study due to the low sample size and the higher incidences of

170 fisheries interactions occurring on shelf waters (Murray and Orphanides 2013). Locations were

171 binned by month to match the resolution of climate projections (Saba et al. 2016) and aggregated

172 over the 10-km resolution AMAPPS spatial grid. The AMAPPS grid was bounded by the

173 coastline to constrain loggerhead space use to the ocean. All maps were prepared with ESRI

174 ArcMAP 10.8. 
175

176

177

178

179

180

181

182

183

184

185

186

\section{Characterizing the Bathythermal Range of Loggerheads}

Although we understand loggerheads are likely influenced by a large range of

environmental variables, our goal was to investigate how the distribution of loggerheads may change in response to warming water temperatures associated with climate change. To model spatial variation in the occurrence of tagged loggerheads and identify the proportion of the observed variation related to water temperature, generalized linear models (GLMs) were applied to estimate the relationship between the probability of loggerhead presence, SST, and depth. We modeled the occurrence, $y_{i t},(0=$ absent, $1=$ present $)$, of tagged turtles in grid cell $i$ during time step $t$ as the outcome of a Bernoulli random variable:

$$
y_{i t} \sim \operatorname{Bernoulli}\left(p_{i t}\right)
$$

where $p_{i t}$ is the probability that a tagged turtle was present. We modeled $p_{i t}$ as a function of SST and depth as:

$$
\operatorname{logit}\left(p_{i t}\right)=\beta_{0,}+\beta_{1} \operatorname{SST}_{i t}+\beta_{2} S S T_{i t}^{2}+\beta_{3} \operatorname{Depth}_{i t}+\beta_{4} \operatorname{Depth}_{i t}^{2}
$$

where the logit link function constrains $p_{i t}$ from 0 to $1, \beta_{0}$ is an intercept term; $\beta_{1}$ and $\beta_{2}$ represent a quadratic effect of SST (which allows for a non-linear relationship); $\beta_{3}$ and $\beta_{4}$ a quadratic effect of bottom depth. Depth data for daily loggerhead locations were obtained from the gridded ETOPO1 bathymetry data set (Amante and Eakins 2009). For observed ocean temperature data (2009 - 2018), we used the Optimum Interpolation Sea Surface Temperature (OISST) product for the same time period of the turtle tracking. OISST is a combination of observations from different platforms (satellites, ships, buoys) and is produced at a $1 / 4^{\circ}$ spatial resolution (Reynolds and Smith 1994). Daily OISST satellite composites were obtained from the NOAA CoastWatch Program (http://coastwatch.pfeg.noaa.gov/erddap/griddap/) using functions 
197 available in the R package 'rerrdap' (Chamberlain 2016) and averaged together to create

198 monthly climatologies to match the output of the climate model projections. These composites

199 were then up-sampled to align with the AMAPPS grid by simple averaging.

200 All model variants were fit via maximum likelihood methods using the package

201 'Template Model Builder' (Kristensen et al. 2016). All parameters were treated as fixed effects;

202 the final gradient value for parameters and the hessian matrix were inspected for each model fit

203 to confirm convergence. We used the Akaike information criterion (AIC; Akaike 1973) and the

204 percent deviance explained (Maunder and Punt 2004) for model selection. Given the small

205 number of explanatory variables considered, we used a forward, step-wise selection approach to

206 identify the most parsimonious combination of regression terms (Zuur et al. 2009). Individual

207 terms were retained in the model if their inclusion resulted in lower AIC values and increased the

208 proportion of the deviance explained relative to the best-fitting model from the previous step. To

209 assess the fit of the selected model and examine potential model misspecification, we examined

210 standard residual diagnostic plots using normalized, randomized residuals (Benjamin et al.

211 2003). Visualizations of model results were produced using functions available in the R package

212 'tidyverse' (Wickham et al. 2019).

\section{Forecasting the distribution of loggerheads under climate change}

214 To investigate how the distribution of loggerheads may shift under climate change, the

215 selected model was fitted to long-term (80 year) projections of SST in the MAB, SNE, GB, and

216 GOM, the most northern portion of loggerhead range within the western Atlantic Ocean (Winton

217 et el. 2018). Projections were based on a climate change scenario from the National Oceanic and

218 Atmospheric Association's (NOAA's) high-resolution global climate model (CM2.6) as

219 described by Saba et al. (2016). Unlike most global climate models that have a warm bias due to 
220 misrepresentation of the position of the Gulf Stream, CM2.6 resolves the Gulf Stream, regional

221 ocean circulation, and bathymetry of the Northwest Atlantic shelf (Saba et al. 2016) much more

222 realistically. Many studies that have projected marine species habitat shifts in the Northwest

223 Atlantic have relied on this climate model (Tanaka et al. 2020, McHenry et al. 2019, Selden et al.

224 2018, Kleisner et al. 2017)

225 The SST output from CM2.6 represents a monthly deviation from a historical average

226 derived from control simulations (deltas). The CM2.6 output was rasterized onto a $0.1^{\circ} \times 0.1^{\circ}$

227 mesh and then synced to the AMAPPS grid. The SST deltas were then added to the mean

228 monthly SST values for the observed time period. Along with depth, which we assumed

229 remained constant, the projected monthly SST was used to project the probability of loggerhead

230 presence from the MAB north to GOM within the continental shelf for 80 years conditioning on

231 the fitted model. For visualization purposes, observed and projected data were grouped into

232 seasons based on both general climate trends for the region and turtle habitat usage patterns

233 (Griffin et al. 2013, Patel et al. 2018, Winton et al. 2018). The projected probability of presence

234 was then averaged across years (10 and 20 year bins). January through March were grouped into

235 winter, April through June to spring, July through September to summer; and October through

236 December to fall.

237 Quantifying climate-related shifts in distribution

238 To better understand and visualize the predicted changes in loggerhead occupancy

239 (presence / absence) under climate change, we developed a binary classifier using the Index of

240 Union (IU) approach to determine whether a cell would be occupied by a loggerhead turtle given

241 the relationships identified (Unal 2017). This analysis was done using the R package "ROCR"

242 (Sing et al. 2005). In short, the IU approach attempts to find an optimal cut point $(c)$ that 
243 correctly classifies the fitted continuous probabilities of loggerhead presence as a 1 (present) or 0

244 (absent). The optimal value of $c$ is that which minimizes the $I U$ criterion:

$$
I U(c)=(|S e(c)-A U C|+|S p(c)-A U C|),
$$

246 where $S e$ is the sensitivity (true positive rate), $S p$ is the specificity (true negative rate), and $A U C$

247 is the Area Under the Receiver Operating Curve. Using the optimal cut-point $(c=0.08)$, we

248 classified seasonal averages of presence probabilities by projected decade to identify cells that

249 could be occupied by loggerhead turtles based on the bathythermal habitat associated with

250 observed loggerhead occupancy patterns. We labeled the IU region classified to have loggerhead

251 presence as the 'core habitat'. The fraction of cells in the study area that could be occupied by

252 loggerheads was then calculated to explore trends in projected occupancy over time. We also

253 calculated the region with the highest probability of presence by taking the top $25 \%$ of the

254 predicated habitat values (Hazen et al. 2013).

\section{Results}

256

257 loggerheads from $2009-2018$

258 were fitted with satellite tags

259 (Table 1). Turtles were either

260 late-stage juveniles or adults

261 with a mean $( \pm \mathrm{SD})$ curved

262 carapace length of $80.0 \pm 9.7$

$263 \mathrm{~cm}$. Filtering the location

264 estimates from these tags
Table 1: Summary information for satellite tag deployments $(\mathrm{CCL}=$ curved carapace length from notch to tip).

\begin{tabular}{|c|c|c|c|}
\hline Year & $\begin{array}{c}\text { Tags } \\
\text { Deployed }\end{array}$ & $\begin{array}{c}\text { Mean } \\
\text { CCL }\end{array}$ & $\begin{array}{c}\text { SD } \\
\text { CCL }\end{array}$ \\
\hline 2009 & 2 & 71.8 & 7.4 \\
\hline 2010 & 14 & 77.8 & 9.2 \\
\hline 2011 & 26 & 79.1 & 7.8 \\
\hline 2012 & 30 & 81.9 & 8.7 \\
\hline 2013 & 16 & 79.2 & 13.4 \\
\hline 2014 & 18 & 78.2 & 9.8 \\
\hline 2015 & 10 & 78.7 & 12.4 \\
\hline 2016 & 21 & 80.4 & 8.6 \\
\hline 2017 & 24 & 78.5 & 12.0 \\
\hline 2018 & 35 & 82.7 & 8.4 \\
\hline \hline Mean & 19.6 & 80.0 & 9.7 \\
\hline
\end{tabular}


265

266

267

268

269

270

271

272

273

274

275

276

277

278

279

280

281

282

283

284

285

286

287

yielded 45,840 daily locations within the NW Atlantic (north of $33.5^{\circ} \mathrm{N}$ and west of $64^{\circ} \mathrm{W}$, the approximate southern and western boundaries of the US northeast continental shelf Large Marine Ecosystem, Link et al. 2008), of which 44,865 daily locations occurred on the continental shelf in the MAB and were used for model fitting.

Model selection for explanatory variables supported a relationship between loggerhead presence, SST, and depth. SST alone explained $15.4 \%$ of the variability in loggerhead presence, while including only bottom depth explained $4.1 \%$. SST and depth combined explained $20.1 \%$ of the variability in loggerhead presence. Based on the fitted model, loggerheads occur at SST between $11.0^{\circ}-29.7^{\circ} \mathrm{C}$ and at depths between $0-105.0 \mathrm{~m}$ (Figures 2a and $2 \mathbf{b}$ ). The overall predicted distribution for each month was consistent with the reconstructed tracks and indicated that the probability of loggerhead presence in the NW Atlantic shelf waters is highest from May through October. Portions of SNE and GB were estimated to have a higher probability of presence than the MAB during summer months.

Using the binary classifier resulted in a core habitat that consisted of temperatures between $15.0^{\circ}-28.0^{\circ} \mathrm{C}$ and depths between 8.0 - $92.0 \mathrm{~m}$ (Figure 2c). The highest probability of presence occurred in regions with SST between $17.7^{\circ}-25.3^{\circ} \mathrm{C}$, and depths between $26.1-$ $74.2 \mathrm{~m}$. More specifically, turtles tended to occupy regions of the MAB with SST closest to $21.5^{\circ} \mathrm{C}$ at depths closest to $50 \mathrm{~m}$.

The CM2.6 model projected that warmer SST would push farther inshore and north through all seasons (Figure 3). Mean SST within the shelf region is expected to gradually increase in the first 40 years, then intensify over the following 40 years. The probability of presence for loggerheads in the NW Atlantic is projected to increase from the observed MayOctober season, to an April - December season within 20 - 60 years, encompassing the entire 
288 spring, summer and fall seasons (Figure 4). In particular, fall is expected to have the largest

289 increase in available thermal habitat for loggerheads, followed by spring (Figure 5). Minimal

290 changes in winter are expected in terms of available suitable habitat over the next 80 years, while

291 available habitat in the summer is expected to slightly decline as the most southern portions of

292 the MAB warm beyond the range of our established temperature envelop.
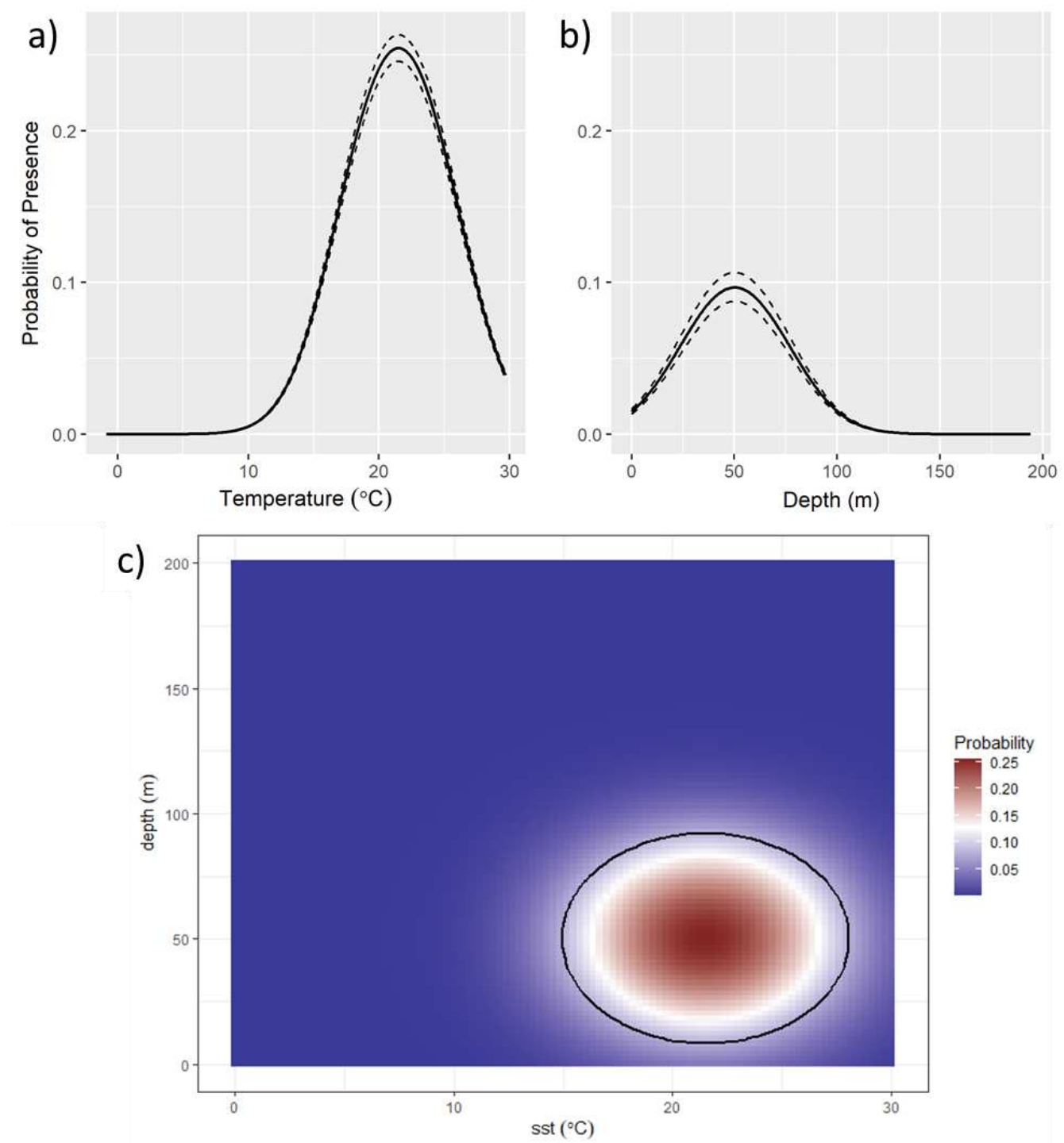

Figure 2: Probability of presence of loggerheads in relation to (a) sea surface temperature (SST) and (b) bottom depth. Dashed lines indicate $95 \%$ confidence intervals. The resulting core habitat as identified using the 'Index of union' is illustrated in (c), where the graph identifying the probability of loggerhead presence from observed data associated with the combined SST and depth ranges and the calculated core habitat (black circle). 


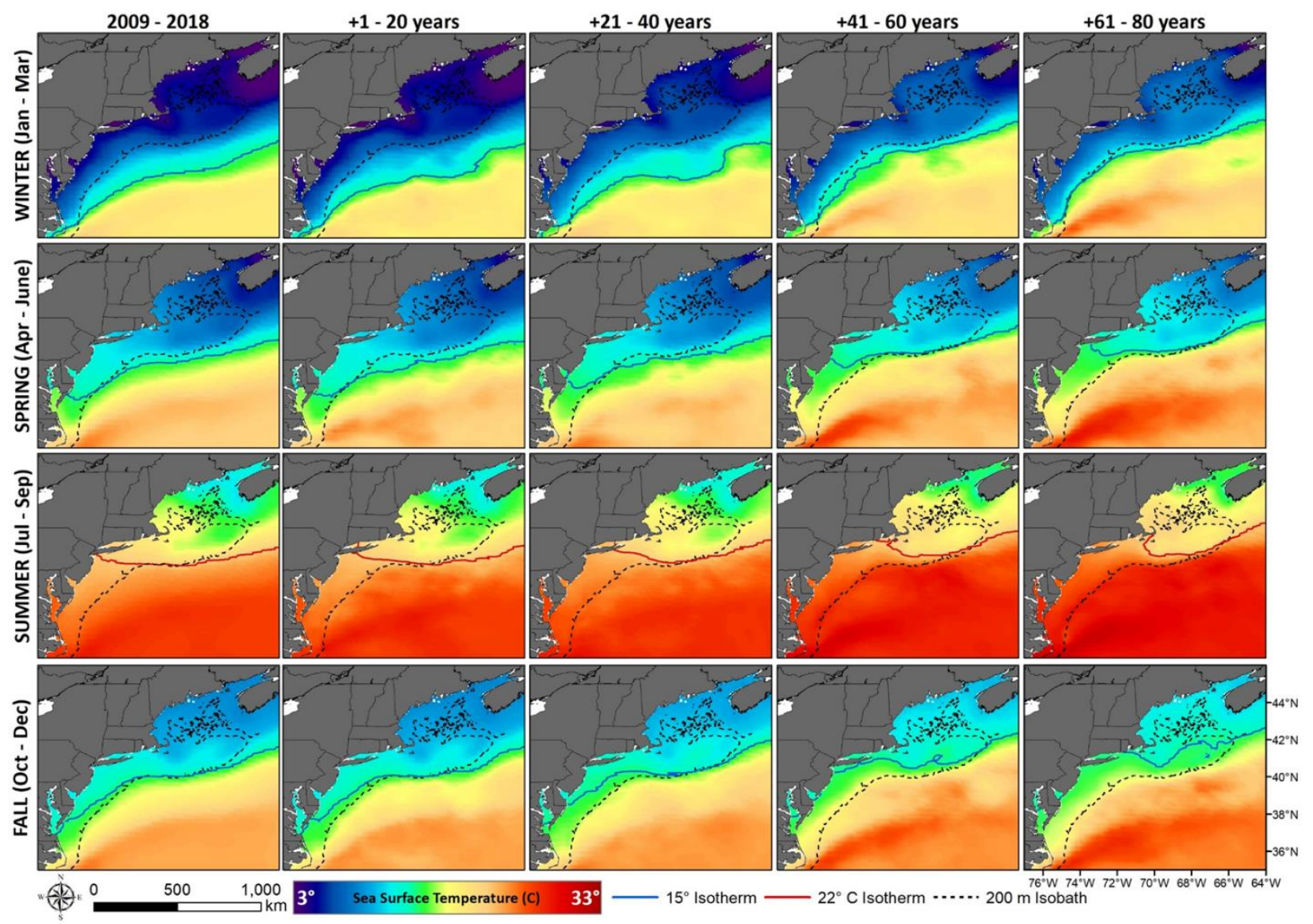

Figure 3: Seasonal maps of historical and projected sea surface temperature in the northwest Atlantic. The north- and shore-ward movement of the Gulf Stream is expected to increasing warming within shelf waters. 


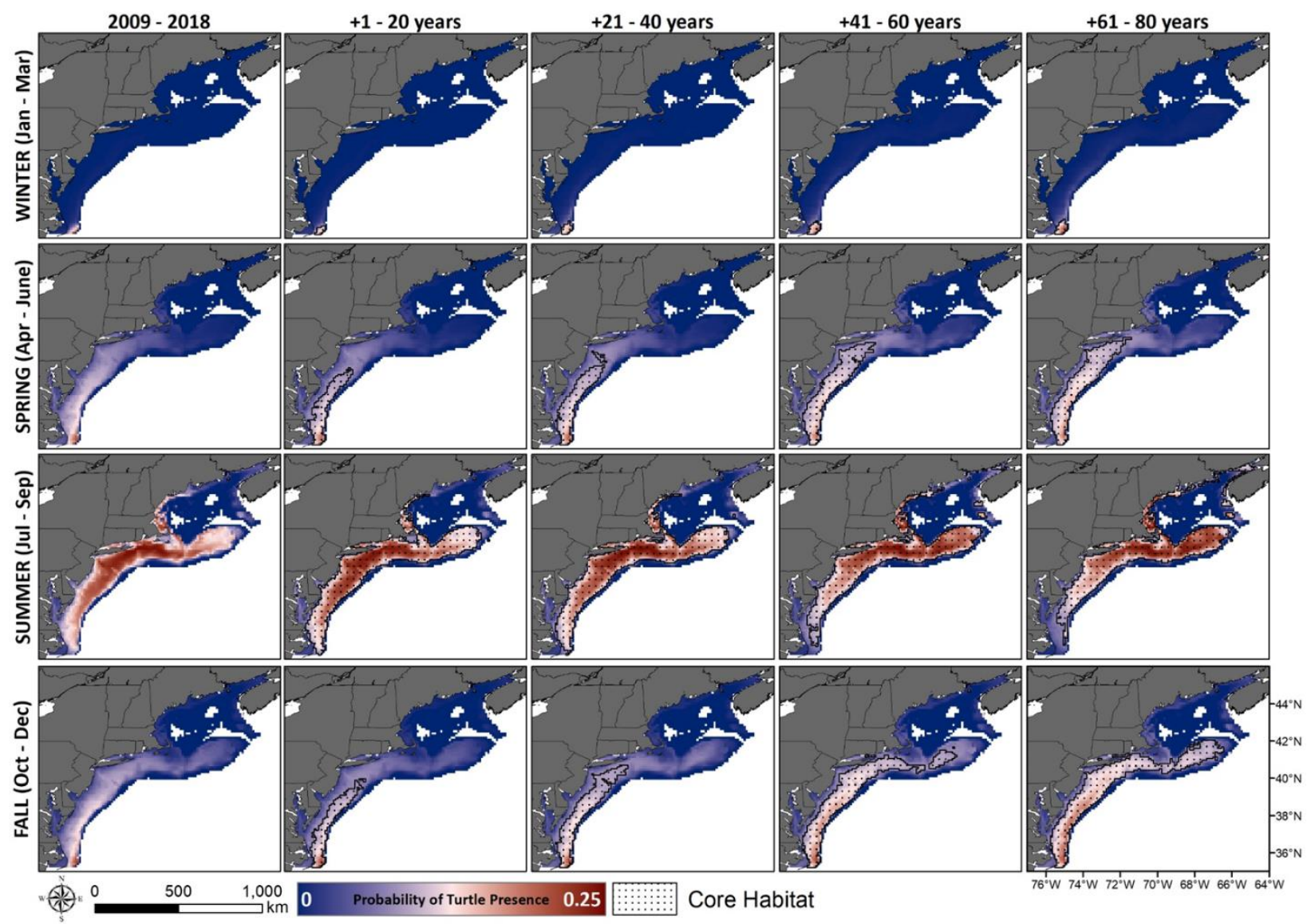

Figure 4: Seasonal maps of probability of turtle presence and core habitat based on observed and projected sea surface temperatures (SST) using the CM2.6 model. Color ramp matches Figure 2c and indicates the probability of presence based on SST and depth. 


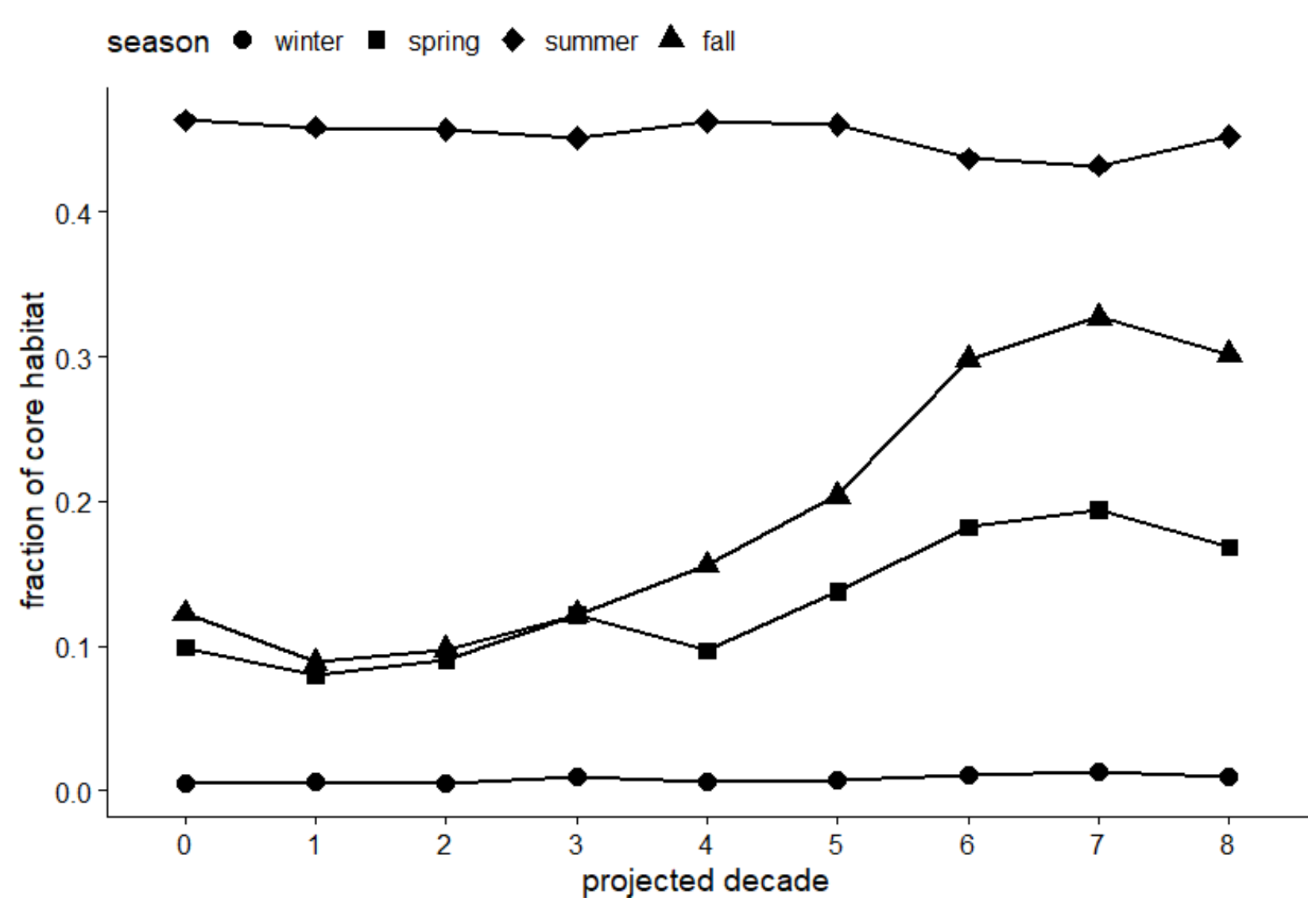

Figure 5: Change in fraction of the NW Atlantic shelf region identified as core habitat for loggerheads across the projected 80 years binned by decade. Spring and fall are projected to have the largest change. Decade ' 0 ' refers to the observed data.

\section{Discussion}

Based on projected increases in SST and the large bathythermal habitat envelope for

309 loggerheads, we project an expansion of potentially suitable loggerhead habitat. The CM2.6

310 model projects a $\sim 3^{\circ} \mathrm{C}$ increase in mean SST for all seasons within $60-80$ years. This increase

311 in SST is not uniform - the GOM is expected to warm faster than the more southern regions

312 (Saba et al. 2016). Shelf waters in the MAB are typically cooler than offshore waters with these

313 two water masses bounded by the Slope Sea, a narrow band of ocean along the continental slope

314 between the shelf and the Gulf Stream (Bane et al. 1988). However, CM2.6 projects a change to 
315 these conditions with the southward flowing cool Arctic waters of the Labrador Current

316 retreating along with a north- and shore-ward shift of the Gulf Stream, allowing warmer water to

317 enter the NW Atlantic shelf region (Saba et al. 2016). These oceanographic features are expected

318 to provide continued suitable bathythermal habitat for loggerheads in the MAB, SNE and GB,

319 and may also expand the range of suitable habitat beyond the observed season (Griffin et al.

320 2013, Winton et al. 2018) and northward into GOM.

Our results matched well with previous research attempting to establish the bathythermal

322 habitat envelope for loggerheads in the region. Hawkes et al. (2007) found that satellite tagged

323 loggerheads had a similar range for temperature $\left(12.8^{\circ}-30.4^{\circ} \mathrm{C}\right)$ and depth $(0.25-104.4 \mathrm{~m})$,

324 while Hawkes et al. (2011) updated these results and narrowed the ranges to $\mathrm{SST}=18.2^{\circ}-29.2^{\circ}$

$325 \mathrm{C}$ and depth $=3-89 \mathrm{~m}$. Additionally, Mansfield et al. (2009) identified that tracked loggerheads

326 that stayed within the neritic zone of the NW Atlantic experienced an SST range between $9.0^{\circ}-$

$32729.3^{\circ} \mathrm{C}$ across all seasons. During the summer the MAB experiences a sharp thermocline with

328 the formation of a Cold Pool water mass that is $\sim 15^{\circ} \mathrm{C}$ cooler than surface waters and occurring

329 near-bottom at depths between 30 - 70 m (Lentz et al. 2017). Loggerheads regularly forage

330 within the Cold Pool (Patel et al. 2018) and those that remain in the shelf waters of the southern

331 US regularly inhabit environments with a much higher SST than observed in the MAB (Iverson

332 et al. 2019). As a result, the habitat envelope estimated from our model may be slightly narrower

333 than the temperature and depth ranges in which loggerheads are able to thrive. Thus loggerhead

334 response may not match the rate of the projected northward shift in their available thermal

335 envelope or their movements may be driven be other correlating factors (Hazen et al. 2013).

336 Despite our use of only two explanatory variables (SST and depth), our model results

337 showed similar patterns of loggerhead distribution to sightings, strandings, and bycatch data, 
338 with slight variations due to the unique practices of each fishery. Braun-McNeill et al. (2008)

339 found that $11^{\circ} \mathrm{C}$ was a conservative minimum SST threshold that aligned well with sea turtle

340 distribution in the NW Atlantic shelf region from ten years of sightings, strandings and bycatch

341 data. Swimmer et al. (2017) identified that loggerheads were most often caught in long lines

342 when SST ranged between $18^{\circ}-24^{\circ} \mathrm{C}$ and hook depth was $22 \mathrm{~m}$ or shallower; however, these

343 results included a much larger portion of the greater Atlantic Ocean. Gillnet bycatch between

344 Massachusetts and North Carolina, having occurred nearly year-round, was within a broader

345 range of SST and depth $\left(\mathrm{SST}=8.6^{\circ}-27.8^{\circ} \mathrm{C}\right.$; depth $=1.8-76.8 \mathrm{~m}$; Murray 2009). Observed

346 bycatch in scallop dredges was limited to SST between $18^{\circ}-25^{\circ} \mathrm{C}$ and depths of $36-68 \mathrm{~m}$

347 (Murray 2011). These values from the scallop fishery aligned closest to our ranges for highest

348 probability of turtle presence $\left(\mathrm{SST}=17.7^{\circ}-25.3^{\circ} \mathrm{C}\right.$ and depths $\left.=26.1-74.2 \mathrm{~m}\right)$ because by-

349 caught turtles in the scallop fishery had a high spatiotemporal overlap with when and where we

350 caught the majority of our tracked loggerheads. Simultaneous integration of multiple data

351 streams during statistical model estimation could help with more robust characterization of

352 habitat envelopes for marine species in addition to this corroborative evidence, particularly for

353 cases with incomplete and imperfect data resolution and could be a target for future research.

We built upon projections calculated by Witt et al. (2010) of suitable loggerhead habitat

355 by developing probability models with monthly projections. Witt et al. (2010) created annual

356 projections using a $15^{\circ} \mathrm{C}$ threshold and suggested that for $90 \%$ of the year the MAB and areas

357 north are unsuitable habitats for loggerheads, even as ocean temperatures warm. However, Witt

358 et al. (2010) added that during summer months, loggerheads would regularly forage farther north

359 than their annualized habitat suitability contours. Results of our winter projections matched well

360 with annualized contours from Witt et al. (2010), indicating that loggerheads would have a very 
361 low probability of entering the MAB during this season, remaining farther south, or potentially in 362 warmer offshore waters. However, throughout the remainder of the year, we projected that the 363 loggerhead thermal habitat envelope would expand into MAB shelf waters earlier in the spring, 364 continue moving north beyond the observed range in SNE and GB, and retreat south later in the 365 fall. This corresponds closely with the trend of the spring and fall $15^{\circ} \mathrm{C}$ SST threshold, with this 366 isotherm continuing north in both shelf and offshore waters throughout the next 80 years.

Although observed data from aerial surveys indicates that SNE and GB are already

368 suitable for loggerheads during portions of the year (Shoop and Kenney 1992), turtles are likely

369 not as abundant farther north due to the shorter thermal window and the existing availability of

370 prey resources in the MAB. With the projected increased thermal window, loggerheads may

371 have more time to explore and actively forage within the northern shelf regions, while reducing

372 competition for prey resources in the more heavily populated MAB, creating higher value to the

373 longer distance migration (Alerstam et al. 2003).

In addition to moving northward, there are likely other loggerhead distribution shifts that

375 could occur as environmental conditions in the NW Atlantic change. For example, if conditions

376 become unsuitable for loggerhead foraging in the MAB, turtles may forage off-shelf for extended

377 periods of time. Our tagging data do indicate that loggerheads venture off-shelf on rare occasions

378 and adult and sub-adult loggerheads have been tracked foraging in pelagic environments

379 throughout the world (Hatase et al. 2002, 2007, Hawkes et al. 2006, Reich et al. 2010). In the

380 MAB, we have documented loggerheads foraging pelagically on jellyfish (Smolowitz et al. 2015,

381 Patel et al. 2016c), and these off-shelf regions adjacent to GOM, GB, MAB and SNE in the

382 Northwest Atlantic are known migratory corridors and feeding grounds for leatherback turtles,

383 obligate jellyfish foragers (James et al. 2005, Dodge et al. 2014). 
As the thermal habitat in the MAB through GB shelf region changes, this will also likely cause shifts in prey densities and species compositions. Using the same CM2.6 global climate model, Kleisner et al. (2017) described the shifts in available thermal habitats for over 30

387 commercially valuable marine species within the NW Atlantic continental shelf. In general, 388 Kleisner et al. (2017) projected the expansion of available thermal habitats for southern species, 389 and the reduction in available thermal habitats for northern species during the spring and fall 390 seasons. Amongst these species, the vulnerability of the Atlantic sea scallop (Placopecten 391 magellanicus) to climate change may provide an indication of how turtles may shift habitat 392 usage. Atlantic sea scallops are a known prey item for loggerheads (Smolowitz et al. 2015) and 393 there is generally a high overlap between loggerhead and sea scallop distribution in the MAB 394 based on preferred depth range (Hart and Chute 2004). Recent research by Rheuban et al. (2018) 395 has found that each scallop stock (MAB and GB) may react differently to climate change and 396 that the more northern GB population may be slightly buffered from negative impacts due to the 397 different mechanisms for larval recruitment between the stocks. However, using changes in 398 ocean temperature and salinity from CM2.6, Tanaka et al. 2020 projected substantial scallop 399 habitat declines throughout the MAB and GB but increased habitat in coastal GOM. As a result, 400 the benthic community could substantially change in the MAB, potentially causing loggerheads 401 to seek other, perhaps more northerly, shelf habitats for prey resources. Shifting distribution as a result of climate change may change interactions of marine 403 species with human uses. Changes to loggerhead range and seasonality may create spatial 404 overlap with fisheries that have not previously needed sea turtle conservation measures. For 405 example, the Atlantic sea scallop fishery developed gear modifications, (Turtle Deflector Dredge 406 and Turtle Chains; Smolowitz et al. 2012) to reduce the bycatch of sea turtles and mandated 
407 these measures for boats fishing in the MAB, specifically west of $-71^{\circ} \mathrm{W}$, from May through

408 November (Framework Adjustment 23 NOAA-NMFS-2011-0255). Our model projects that

409 within the next 20 - 40 years, loggerheads could forage within the NW Atlantic shelf region

410 outside the spatial and temporal range these scallop gear modifications are required. Because the

411 scallop industry has already developed a dredge effective at reducing turtle bycatch, adjusting the

412 gear to remain efficient in the more northern scalloping grounds and expanding its usage could

413 be an effective solution with minimal economic impacts to the fishery (Smolowitz et al. 2012).

414 However, northern fisheries that use pelagic long lines, trawls and gillnets have the potential to

415 see increases in turtle bycatch if fisheries management does not adapt to projected environmental

416 changes. For example, the bottom trawl fishery operating in the MAB, SNE and GB, from 2014

$417-2018$, had the highest number of estimated sea turtle interactions occur north of $39^{\circ} \mathrm{N}$, which is

418 farther north than in previous years (Murray 2020).

419 Overall, sea turtle seasonal habitat usage and distribution is likely linked to a broader

420 range of environmental variables beyond SST and depth (Hazen et al. 2013), as well as

421 biological factors like the availability of prey resources (Houghton et al. 2006), reproductive

422 cycles and life stage (Nelson 1988). However, given the availability of data and what is known

423 about loggerhead ecology in general, the type of bioclimatic envelope model we present provides

424 a reasonable assessment of the potential drivers for the distribution of this cohort of loggerheads

425 (Araujo and Townsend Peterson 2012). To truly determine how climate change will impact these

426 turtles will require continuous monitoring, particularly in the MAB, SNE and GB. Our results

427 can guide expectations for likely future turtle distributions and inform discussions to plan for

428 reasonable conservation measures. If future conservation measures and turtle distribution need to

429 be synchronized, additional monitoring and adaptive management will be necessary. 
430

431

432

433

434 provided analytical expertise. All authors developed and reviewed the manuscript.

\section{Acknowledgements}

436

437 scientists on the F/V Kathy Ann and F/V Ms Manya for their expert field work. Leah Crowe,

438 Kathryn Goetting, Eric Matzen, Henry Milliken, Shea Miller, Liese Siemann, Brianna Valenti,

439 Daniel Ward, and Matthew Weeks were integral to the success of this project. This study was

440 funded in part by the scallop industry Sea Scallop Research Set Aside program administered by

441 the Northeast Fisheries Science Center, by the U.S. Department of the Interior, Bureau of Ocean

442 Energy Management through Interagency Agreement M19PG00007 with the U.S. Department of

443 the Commerce, National Oceanic and Atmospheric Administration (NOAA), National Marine

444 Fisheries Service (NMFS), Northeast Fisheries Science Center (NEFSC), by the National

445 Oceanic and Atmospheric Administration Saltonstall-Kennedy Grant Program, and by the

446 National Marine Fisheries Protected Species Toolbox Initiative.

\section{$447 \quad$ Literature Cited}

448 Akaike H, 1973. Maximum likelihood identification of Gaussian autoregressive moving average 449 models. Biometrika, 60(2), pp.255-265. 
450 Albertsen CM, Whoriskey K, Yurkowski D, Nielsen A, Flemming JM. 2015. Fast fitting of non451 Gaussian state-space models to animal movement data via Template Model Builder. Ecology. 452 96(10):2598-2604.

453 Alerstam T, Hedenström A, Åkesson S. 2003. Long-distance migration: evolution and 454 determinants. Oikos. 103(2):247-60.

455 Amante C, Eakins BW. 2009. ETOPO1 arc-minute global relief model: procedures, data sources 456 and analysis. NOAA Technical Memorandum NESDIS NGDC-24.

457 Araújo MB, Townsend Peterson A. 2012. Uses and misuses of bioclimatic envelope modeling. 458 Ecology. 93(7):1527-39.

459 Bane Jr JM, Brown OB, Evans RH, Hamilton P. 1988. Gulf Stream remote forcing of shelfbreak 460 currents in the Mid-Atlantic Bight. Geophysical research letters. 15(5):405-7.

461 Benjamin MA, Rigby RA, Stasinopoulos DM. 2003. Generalized autoregressive moving average 462 models. Journal of the American Statistical association. 98(461):214-23.

463 Bivand R, Piras G. 2015. Comparing implementations of estimation methods for spatial 464 econometrics. American Statistical Association.

465 Braun-McNeill J, Sasso CR, Epperly SP, Rivero C. 2008. Feasibility of using sea surface 466 temperature imagery to mitigate cheloniid sea turtle-fishery interactions off the coast of 467 northeastern USA. Endangered Species Research. 5(2-3):257-66.

468 Cañadas A, Hammond PS. 2008. Abundance and habitat preferences of the short-beaked 469 common dolphin Delphinus delphis in the southwestern Mediterranean: implications for 470 conservation. Endangered species research. 4(3):309-31. 
471 Ceriani SA, Weishampel JF, Ehrhart LM, Mansfield KL, Wunder MB. 2017. Foraging and

472 recruitment hotspot dynamics for the largest Atlantic loggerhead turtle rookery. Scientific

473 reports. 7(1):1-3.

474 Chamberlain, S. 2016. rerddap - General purpose client for 'ERDDAP' servers. R Package.

475 Clay PM. 1996. Management regions, statistical areas and fishing grounds: Criteria for dividing 476 up the sea. Journal of Northwest Atlantic Fishery Science. 19.

477 Coles W, Musick JA. 2000. Satellite sea surface temperature analysis and correlation with sea 478 turtle distribution off North Carolina. Copeia. 2000(2):551-4.

479 Crowe LM, Hatch JM, Patel SH, Smolowitz RJ, Haas HL. 2020. Riders on the storm: loggerhead 480 sea turtles detect and respond to a major hurricane in the Northwest Atlantic Ocean. Movement 481 ecology. 8(1):1-3.

482 Dodge KL, Galuardi B, Miller TJ, Lutcavage ME. 2014. Leatherback turtle movements, dive 483 behavior, and habitat characteristics in ecoregions of the Northwest Atlantic Ocean. PLoS One. 484 9(3):e91726.

485 Dunn DC, Boustany AM, Halpin PN. 2011. Spatio-temporal management of fisheries to reduce 486 by-catch and increase fishing selectivity. Fish and Fisheries. 12(1):110-9.

487 Framework Adjustment 23 to the Scallop Fisheries Management Plan. 2012. NOAA-NMFS$488 \quad 2011-0255$.

489 Fofonoff NP. 1981. The Gulf Stream. Evolution of Physical Oceanography: Scientific Surveys in 490 Honor of Henry Stommel, BA Warren and C. Wunsch, eds., MIT Press, Cambridge, MA. 11249139. 
492 Franco AM, Catry I, Sutherland WJ, Palmeirim JM. 2004. Do different habitat preference survey 493 methods produce the same conservation recommendations for lesser kestrels? Animal 494 Conservation. 7(3):291-300.

495 Gilman P, Maurer B, Feinberg L, Duerr A, Peterson L, Musial W, Beiter P, Golladay J, 496 Stromberg J, Johnson I, Boren D. 2016. National offshore wind strategy: facilitating the 497 development of the offshore wind industry in the United States. National Renewable Energy 498 Lab.(NREL), Golden, CO (United States).

499 Griffin DB, Murphy SR, Frick MG, Broderick AC, Coker JW, Coyne MS, Dodd MG, Godfrey 500 MH, Godley BJ, Hawkes LA, Murphy TM. 2013. Foraging habitats and migration corridors 501 utilized by a recovering subpopulation of adult female loggerhead sea turtles: implications for 502 conservation. Marine Biology. 160(12):3071-86.

503 Hart DR, Chute AS. 2004. Essential fish habitat source document: Sea scallop, Placopecten 504 magellanicus, life history and habitat characteristics. NOAA Tech Memo NMFS NE. 189:21.

505 Hart KM, Hyrenbach KD. 2009. Satellite telemetry of marine megavertebrates: the coming of 506 age of an experimental science. Endangered Species Research. 10:9-20.

507 Hatase H, Omuta K, Tsukamoto K. 2007. Bottom or midwater: alternative foraging behaviours 508 in adult female loggerhead sea turtles. Journal of Zoology. 273(1):46-55.

509 Hatase H, Takai N, Matsuzawa Y, Sakamoto W, Omuta K, Goto K, Arai N, Fujiwara T. 2002.

510 Size-related differences in feeding habitat use of adult female loggerhead turtles Caretta caretta 511 around Japan determined by stable isotope analyses and satellite telemetry. Marine Ecology 512 Progress Series. 233:273-81. 
513 Hawkes LA, Broderick AC, Coyne MS, Godfrey MH, Lopez-Jurado LF, Lopez-Suarez P,

514 Merino SE, Varo-Cruz N, Godley BJ. 2006. Phenotypically linked dichotomy in sea turtle

515 foraging requires multiple conservation approaches. Current Biology. 16(10):990-5.

516 Hawkes LA, Broderick AC, Coyne MS, Godfrey MH, Godley BJ. 2007. Only some like it hot-

517 quantifying the environmental niche of the loggerhead sea turtle. Diversity and distributions.

518 13(4):447-57.

519 Hays GC, Hawkes LA. 2018. Satellite Tracking Sea turtles: opportunities and challenges to

520 address key questions. Frontiers in Marine Science. 5:432.

521 Hazen EL, Jorgensen S, Rykaczewski RR, Bograd SJ, Foley DG, Jonsen ID, Shaffer SA, Dunne

522 JP, Costa DP, Crowder LB, Block BA. 2013. Predicted habitat shifts of Pacific top predators in a 523 changing climate. Nature Climate Change. 3(3):234-8.

524 Hebblewhite M, Haydon DT. 2010. Distinguishing technology from biology: a critical review of 525 the use of GPS telemetry data in ecology. Philosophical Transactions of the Royal Society B:

526 Biological Sciences. 365(1550):2303-12.

527 Houghton JD, Doyle TK, Wilson MW, Davenport J, Hays GC. 2006. Jellyfish aggregations and 528 leatherback turtle foraging patterns in a temperate coastal environment. Ecology. 87(8):1967-72.

529 Howell EA, Kobayashi DR, Parker DM, Balazs GH, Polovina JJ. 2008. TurtleWatch: a tool to 530 aid in the bycatch reduction of loggerhead turtles Caretta caretta in the Hawaii-based pelagic 531 longline fishery. Endangered Species Research. 5(2-3):267-78. 
532 IPCC. 2014. Climate Change 2014: Synthesis Report. Contribution of Working Groups I, II and

533 III to the Fifth Assessment Report of the Intergovernmental Panel on Climate Change [Core

534 Writing Team, R.K. Pachauri and L.A. Meyer (eds.)]. IPCC, Geneva, Switzerland, 151 pp.

535 Iverson AR, Fujisaki I, Lamont MM, Hart KM. 2019. Loggerhead sea turtle (Caretta caretta)

536 diving changes with productivity, behavioral mode, and sea surface temperature. PloS one.

537 14(8):e0220372.

538 James MC, Andrea Ottensmeyer C, Myers RA. 2005. Identification of high-use habitat and

539 threats to leatherback sea turtles in northern waters: new directions for conservation. Ecology

540 letters. 8(2):195-201.

541 Johnson DS, London JM, Lea M-A, Durban JW. 2008. Continuous-Time Correlated Random

542 Walk Model for Animal Telemetry Data. Ecology. 89(5):1208-1215.

543 Kleisner KM, Fogarty MJ, McGee S, Hare JA, Moret S, Perretti CT, Saba VS. 2017. Marine

544 species distribution shifts on the US Northeast Continental Shelf under continued ocean

545 warming. Progress in Oceanography. 153:24-36.

546 Kristensen K, Nielsen A, Berg CW, Skaug H, Bell BM. 2016. TMB: Automatic Differentiation

547 and Laplace Approximation. Journal of Statistical Software. 70(5):1-21

548 Lentz SJ. 2017. Seasonal warming of the Middle Atlantic Bight Cold Pool. Journal of

549 Geophysical Research: Oceans. 122(2):941-54.

550 Link J, Overholtz W, O'Reilly J, Green J, Dow D, Palka D, Legault C, Vitaliano J, Guida V,

551 Fogarty M, Brodziak J. 2008. The Northeast US continental shelf Energy Modeling and Analysis 
552 exercise (EMAX): Ecological network model development and basic ecosystem metrics. Journal 553 of Marine Systems. 74(1-2):453-74.

554 Mansfield KL, Saba VS, Keinath JA, Musick JA. 2009. Satellite tracking reveals a dichotomy in

555 migration strategies among juvenile loggerhead turtles in the Northwest Atlantic. Marine 556 Biology. 156(12):2555-70.

557 Mawdsley JR, O’malley R, Ojima DS. 2009. A review of climate-change adaptation strategies

558 for wildlife management and biodiversity conservation. Conservation Biology. 23(5):1080-9.

559 McHenry J, Welch H, Lester SE, Saba V. 2019. Projecting marine species range shifts from only

560 temperature can mask climate vulnerability. Global change biology. 25(12):4208-21.

561 Murray KT. 2009. Characteristics and magnitude of sea turtle bycatch in US mid-Atlantic gillnet 562 gear. Endangered Species Research. 8(3):211-24.

563 Murray KT. 2011. Interactions between sea turtles and dredge gear in the US sea scallop

564 (Placopecten magellanicus) fishery, 2001-2008. Fisheries Research. 107(1-3):137-46.

565 Murray KT. 2020. Estimated Magnitude of Sea Turtle Interactions and Mortality in US Bottom 566 Trawl Gear, 2014-2018.

567 Murray KT, Orphanides CD. 2013. Estimating the risk of loggerhead turtle Caretta caretta 568 bycatch in the US mid-Atlantic using fishery-independent and-dependent data. Marine Ecology 569 Progress Series. 477:259-70.

570 Nelson DA. 1988. Life history and environmental requirements of loggerhead turtles. Fish and 571 Wildlife Service, US Department of the Interior. 
572 Northeast Fisheries Science Center (NEFSC) and Southeast Fisheries Science Center (SEFSC).

573 2011. Preliminary summer 2010 regional abundance estimate of loggerhead turtles (Caretta

574 caretta) in northwestern Atlantic Ocean continental shelf waters. US Dept Commer, Northeast

575 Fish Sci Cent Ref Doc. 11-03; 33 p.

576 Patel SH, Morreale SJ, Saba VS, Panagopoulou A, Margaritoulis D, Spotila JR. 2016a. Climate

577 impacts on sea turtle breeding phenology in Greece and associated foraging habitats in the wider

578 Mediterranean region. PLoS One. 11(6):e0157170.

579 Patel SH, Miller S, Smolowitz RJ. 2016b. Understanding impacts of the sea scallop fishery on

580 loggerhead sea turtles through satellite tagging. Final report for 2015 Sea Scallop Research Set-

581 Aside (RSA). NOAA grant: NA15 NMF 4540055. Coonamessett Farm Foundation, East

582 Falmouth, MA.

583 Patel SH, Dodge KL, Haas HL, Smolowitz RJ. 2016c. Videography reveals in-water behavior of

584 loggerhead turtles (Caretta caretta) at a foraging ground. Frontiers in Marine Science. 3:254.

585 Patel SH, Barco SG, Crowe LM, Manning JP, Matzen E, Smolowitz RJ, Haas HL. 2018.

586 Loggerhead turtles are good ocean-observers in stratified mid-latitude regions. Estuarine, Coastal

587 and Shelf Science. 213:128-36.

588 Pinsky ML, Selden RL, Kitchel ZJ. 2020. Climate-Driven Shifts in Marine Species Ranges:

589 Scaling from Organisms to Communities. Annual Review of Marine Science. 12:153-79.

590 Poloczanska ES, Brown CJ, Sydeman WJ, Kiessling W, Schoeman DS, Moore PJ, Brander K,

591 Bruno JF, Buckley LB, Burrows MT, Duarte CM. 2013. Global imprint of climate change on

592 marine life. Nature Climate Change. 3(10):919-25. 
593 R Core Team. 2017. R: A language and environment for statistical computing.

594 Reich KJ, Bjorndal KA, Frick MG, Witherington BE, Johnson C, Bolten AB. 2010. Polymodal

595 foraging in adult female loggerheads (Caretta caretta). Marine Biology. 157(1):113-21.

596 Reynolds RW, Smith TM. 1994. Improved global sea surface temperature analyses using

597 optimum interpolation. Journal of climate. 7(6):929-48.

598 Rheuban JE, Doney SC, Cooley SR, Hart DR. 2018. Projected impacts of future climate change,

599 ocean acidification, and management on the US Atlantic sea scallop (Placopecten magellanicus)

600 fishery. PLoS One. 13(9):e0203536.

601 Roe JH, Morreale SJ, Paladino FV, Shillinger GL, Benson SR, Eckert SA, Bailey H, Tomillo PS,

602 Bograd SJ, Eguchi T, Dutton PH. 2014. Predicting bycatch hotspots for endangered leatherback

603 turtles on longlines in the Pacific Ocean. Proceedings of the Royal Society B: Biological

604 Sciences. 281(1777):20132559.

605 Saba VS, Stock CA, Spotila JR, Paladino FV, Tomillo PS. 2012. Projected response of an

606 endangered marine turtle population to climate change. Nature Climate Change. 2(11):814-20.

607 Saba VS, Griffies SM, Anderson WG, Winton M, Alexander MA, Delworth TL, Hare JA,

608 Harrison MJ, Rosati A, Vecchi GA, Zhang R. 2016. Enhanced warming of the Northwest

609 Atlantic Ocean under climate change. Journal of Geophysical Research: Oceans. 121(1):118-32.

610 Selden RL, Batt RD, Saba VS, Pinsky ML. 2018. Diversity in thermal affinity among key

611 piscivores buffers impacts of ocean warming on predator-prey interactions. Global change

612 biology. 24(1):117-31. 
613 Senko J, White ER, Heppell SS, Gerber LR. 2014. Comparing bycatch mitigation strategies for 614 vulnerable marine megafauna. Animal Conservation. 17(1):5-18.

615 Shoop CR, Kenney RD. 1992. Seasonal distributions and abundances of loggerhead and 616 leatherback sea turtles in waters of the northeastern United States. Herpetological Monographs. $617 \quad 43-67$.

618 Sing T, Sander O, Beerenwinkel N, Lengauer T. 2005. ROCR: visualizing classifier performance 619 in R. Bioinformatics. 21(20):7881.

620 Smolowitz R, Milliken HO, Weeks M. 2012. Design, evolution, and assessment of a sea turtle 621 deflector dredge for the US Northwest Atlantic sea scallop fishery: impacts on fish bycatch.

622 North American journal of fisheries management. 32(1):65-76.

623 Smolowitz RJ, Patel SH, Haas HL, Miller SA. 2015. Using a remotely operated vehicle (ROV)

624 to observe loggerhead sea turtle (Caretta caretta) behavior on foraging grounds off the mid625 Atlantic United States. Journal of Experimental Marine Biology and Ecology. 471:84-91.

626 Spotila JR, Reina RD, Steyermark AC, Plotkin PT, Paladino FV. 2000. Pacific leatherback 627 turtles face extinction. Nature. 405(6786):529-30.

628 Stoneburner DL. 1982. Satellite telemetry of loggerhead sea turtle movement in the Georgia 629 Bight. Copeia. 400-8.

630 Swimmer Y, Gutierrez A, Bigelow K, Barceló C, Schroeder B, Keene K, Shattenkirk K, Foster 631 DG. 2017. Sea turtle bycatch mitigation in US longline fisheries. Frontiers in Marine Science. $6324: 260$. 
633 Tanaka KR, Torre MP, Saba VS, Stock CA, Chen Y. 2020. An ensemble high-resolution

634 projection of changes in the future habitat of American lobster and sea scallop in the Northeast

635 US continental shelf. Diversity and Distributions.

636 Tomillo PS, Saba VS, Lombard CD, Valiulis JM, Robinson NJ, Paladino FV, Spotila JR,

637 Fernández C, Rivas ML, Tucek J, Nel R. 2015. Global analysis of the effect of local climate on

638 the hatchling output of leatherback turtles. Scientific reports. 5:16789.

639 Turtle Expert Working Group (TEWG). 2009. An assessment of the loggerhead turtle population

640 in the western North Atlantic Ocean. NOAA Technical Memorandum NMFS-SEFSC.

$641 \quad 575(131): 744$.

642 Tyberghein L, Verbruggen H, Pauly K, Troupin C, Mineur F, De Clerck O. 2012. Bio-ORACLE:

643 a global environmental dataset for marine species distribution modelling. Global ecology and

644 biogeography. 21(2):272-81.

645 Unal I. 2017. Defining an optimal cut-point value in ROC analysis: an alternative approach.

646 Computational and mathematical methods in medicine.

647 Wallace BP, Kot CY, DiMatteo AD, Lee T, Crowder LB, Lewison RL. 2013. Impacts of 648 fisheries bycatch on marine turtle populations worldwide: toward conservation and research 649 priorities. Ecosphere. 4(3):1-49.

650 Warden ML. 2011. Modeling loggerhead sea turtle (Caretta caretta) interactions with US Mid651 Atlantic bottom trawl gear for fish and scallops, 2005-2008. Biological Conservation.

652 144(9):2202-12. 
653 Weatherdon LV, Magnan AK, Rogers AD, Sumaila UR, Cheung WW. 2016. Observed and

654 projected impacts of climate change on marine fisheries, aquaculture, coastal tourism, and

655 human health: an update. Frontiers in Marine Science. 3:48.

656 Wickham H, Averick M, Bryan J, Chang W, McGowan LD, François R, Grolemund G, Hayes

657 A, Henry L, Hester J, Kuhn M. Welcome to the Tidyverse. 2019. Journal of Open Source

658 Software. 4(43):1686.

659 Winton MV, Fay G, Haas HL, Arendt M, Barco S, James MC, Sasso C, Smolowitz R. 2018.

660 Estimating the distribution and relative density of satellite-tagged loggerhead sea turtles using

661 geostatistical mixed effects models. Marine Ecology Progress Series. 586:217-32.

662 Witt MJ, Hawkes LA, Godfrey MH, Godley BJ, Broderick AC. 2010. Predicting the impacts of

663 climate change on a globally distributed species: the case of the loggerhead turtle. Journal of

664 Experimental Biology. 213(6):901-11.

665 Zuur A, Ieno EN, Walker N, Saveliev AA, Smith GM. 2009. Mixed effects models and

666 extensions in ecology with R. Springer Science \& Business Media. 
Figures

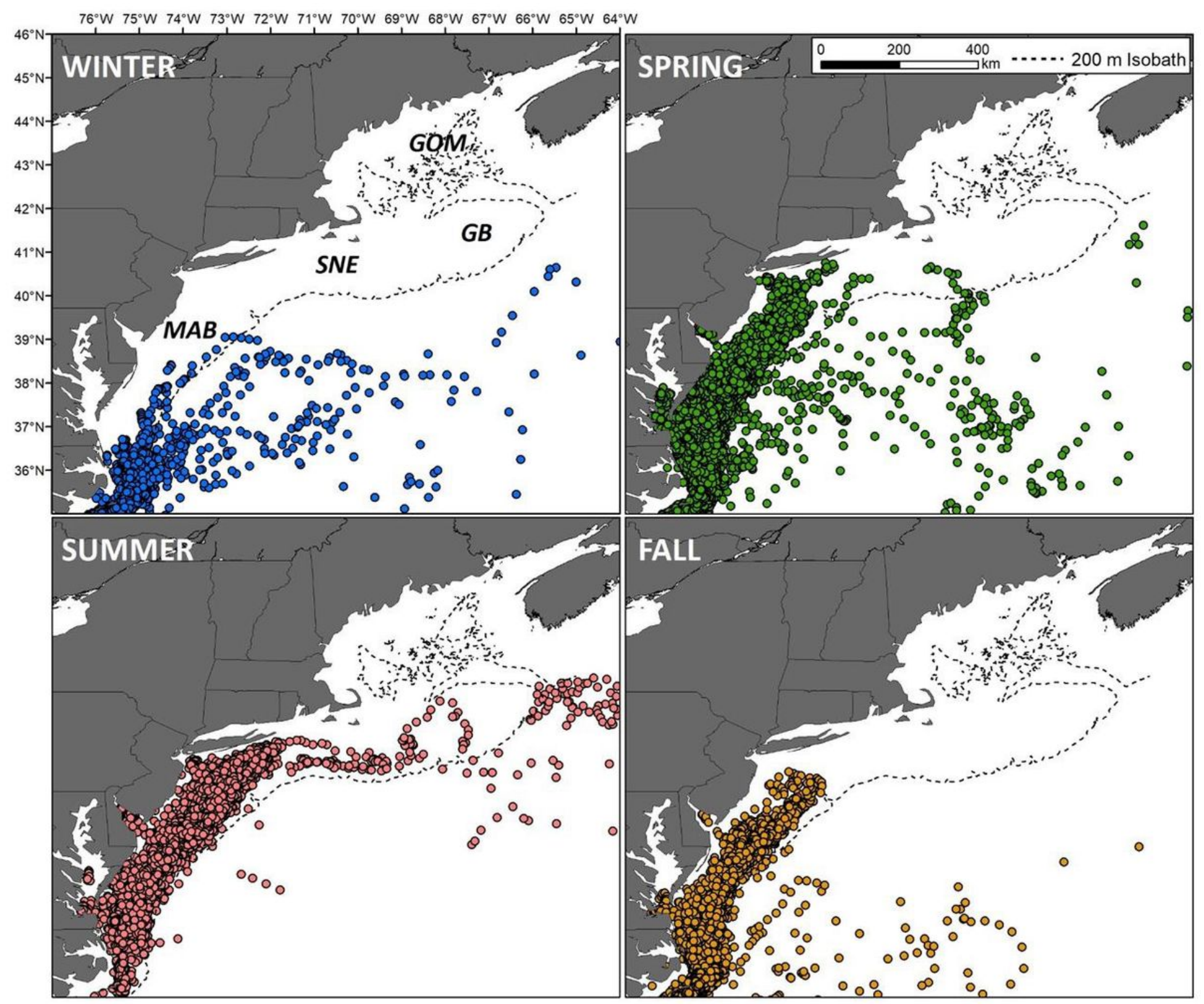

Figure 1

Reconstructed tracks from 196 loggerhead sea turtles satellite tagged between 20092018 within the northwest Atlantic. Dashed lines denote the $200 \mathrm{~m}$ bathymetric contour. GOM = Gulf of Maine, GB = Georges Bank, SNE = Southern New England, and MAB = Middle Atlantic Bight. 


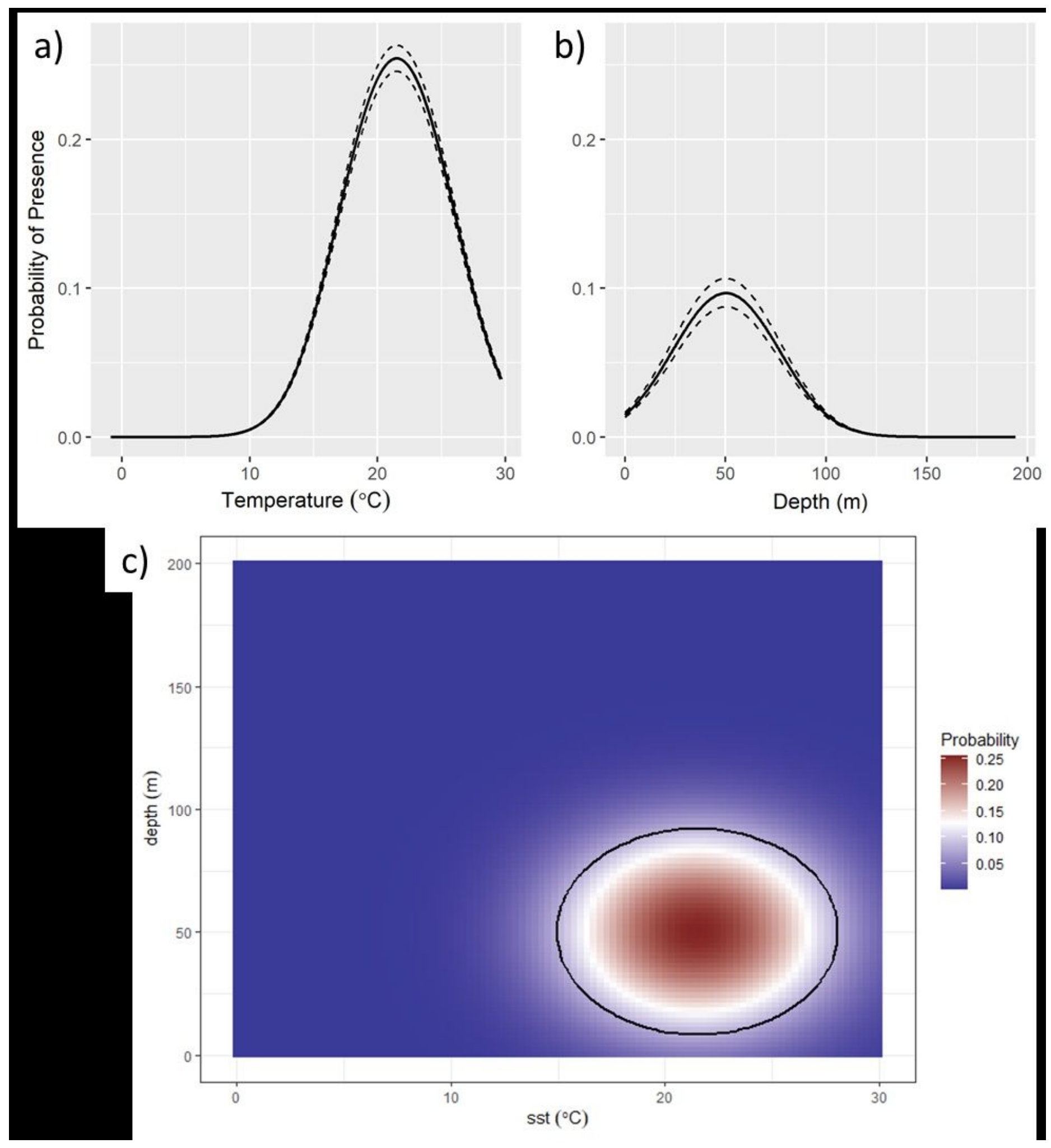

Figure 2

Probability of presence of loggerheads in relation to (a) sea surface temperature (SST) and (bottom depth. Dashed lines indicate $95 \%$ confidence intervals. The resulting core habitat as identified using the 'Index of union' is illustrated in (c), where the graph identifying the probability of loggerhead presence from observed data associated with the combined SST and depth ranges and the calculated core habitat (black circle). 


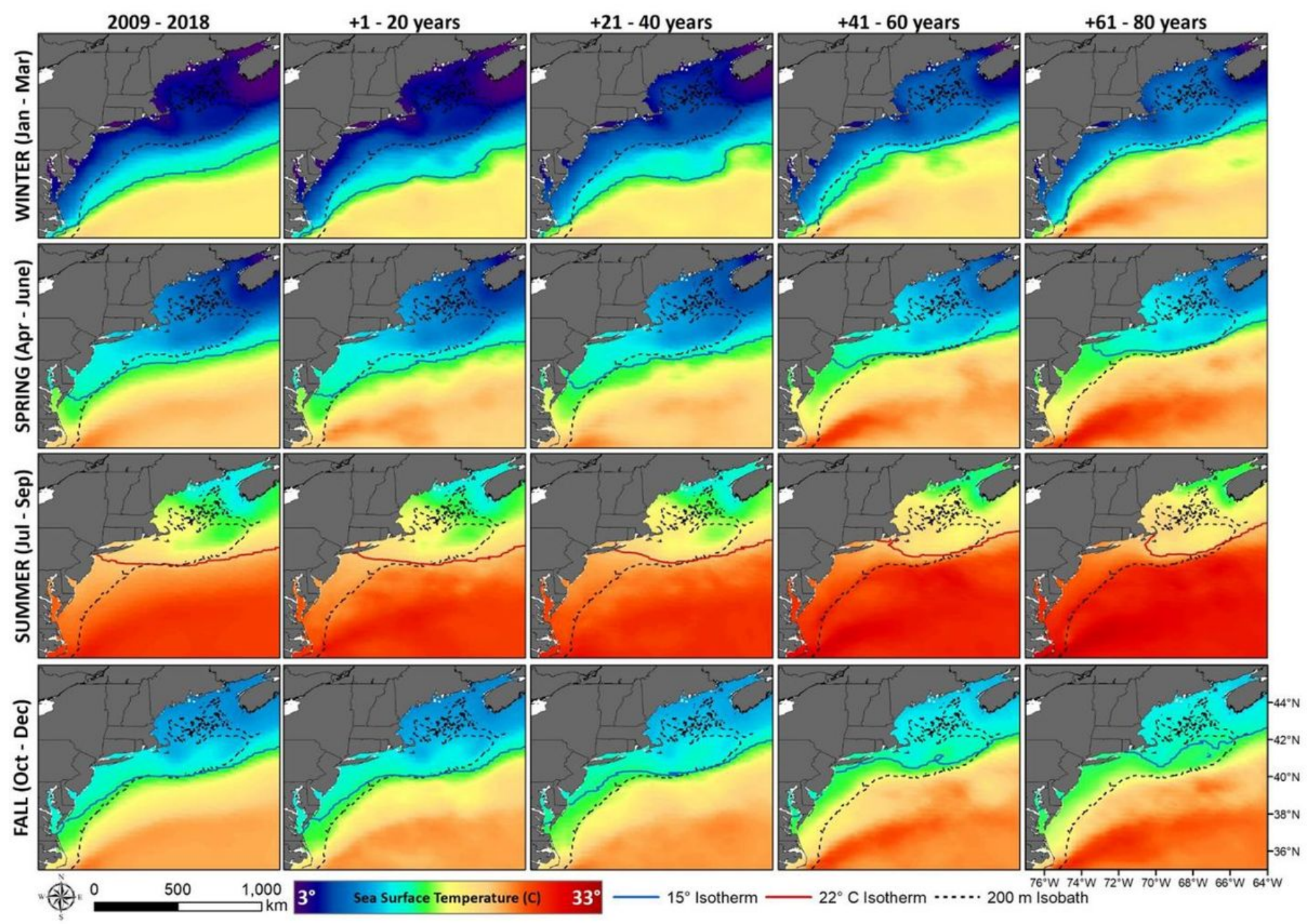

Figure 3

Seasonal maps of historical and projected sea surface temperature in the northwest Atlantic The north and shore ward movement of the Gulf Stream is expected to increasing warming within shelf waters. 


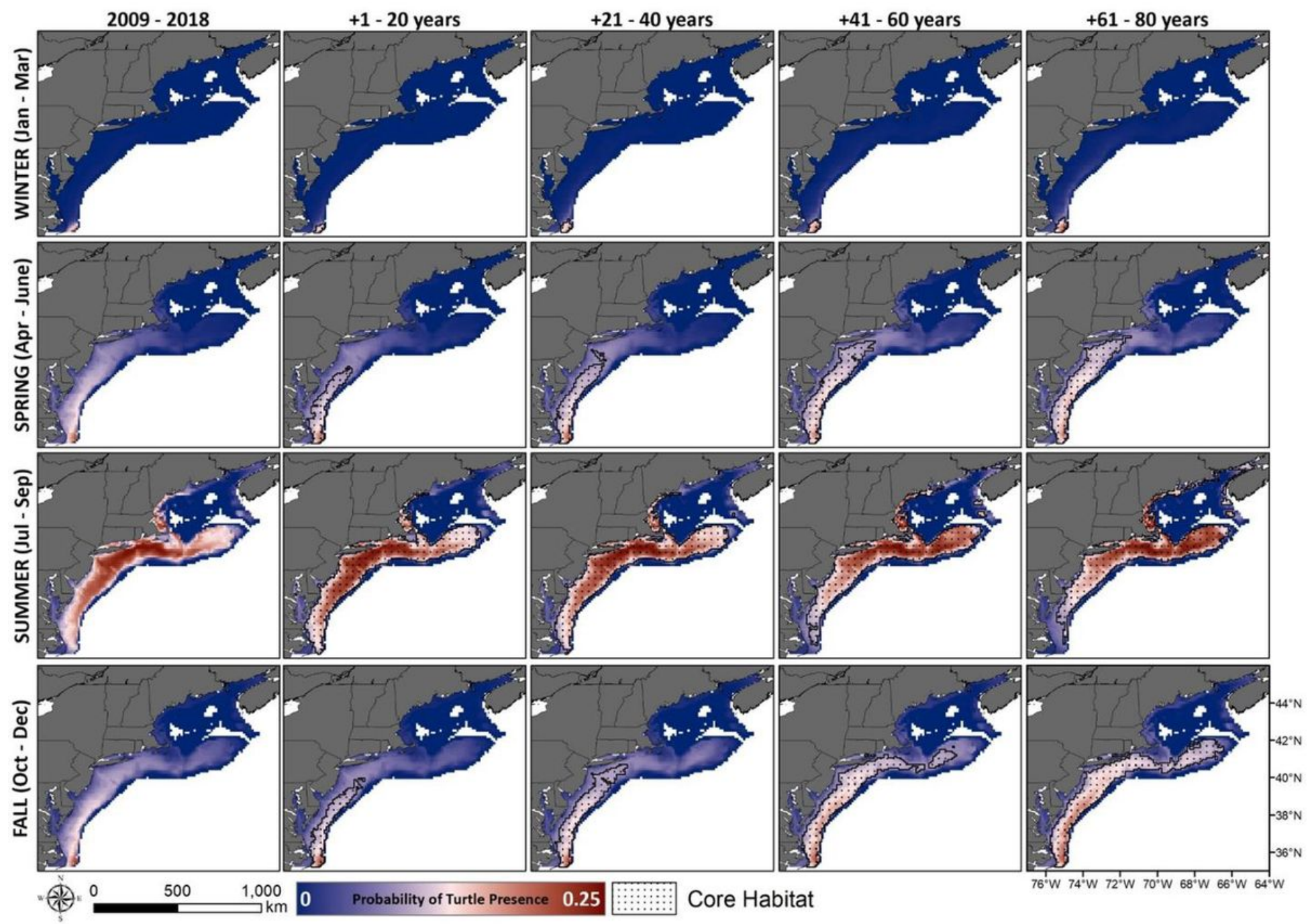

Figure 4

Seasonal maps of probability of tur tle presence and core habitat based on observed and projected sea surface temperatures (SST) using the CM2.6 model. Color ramp matches Figure $2 \mathrm{c}$ and indicates the probability of presence based on SST and depth. 


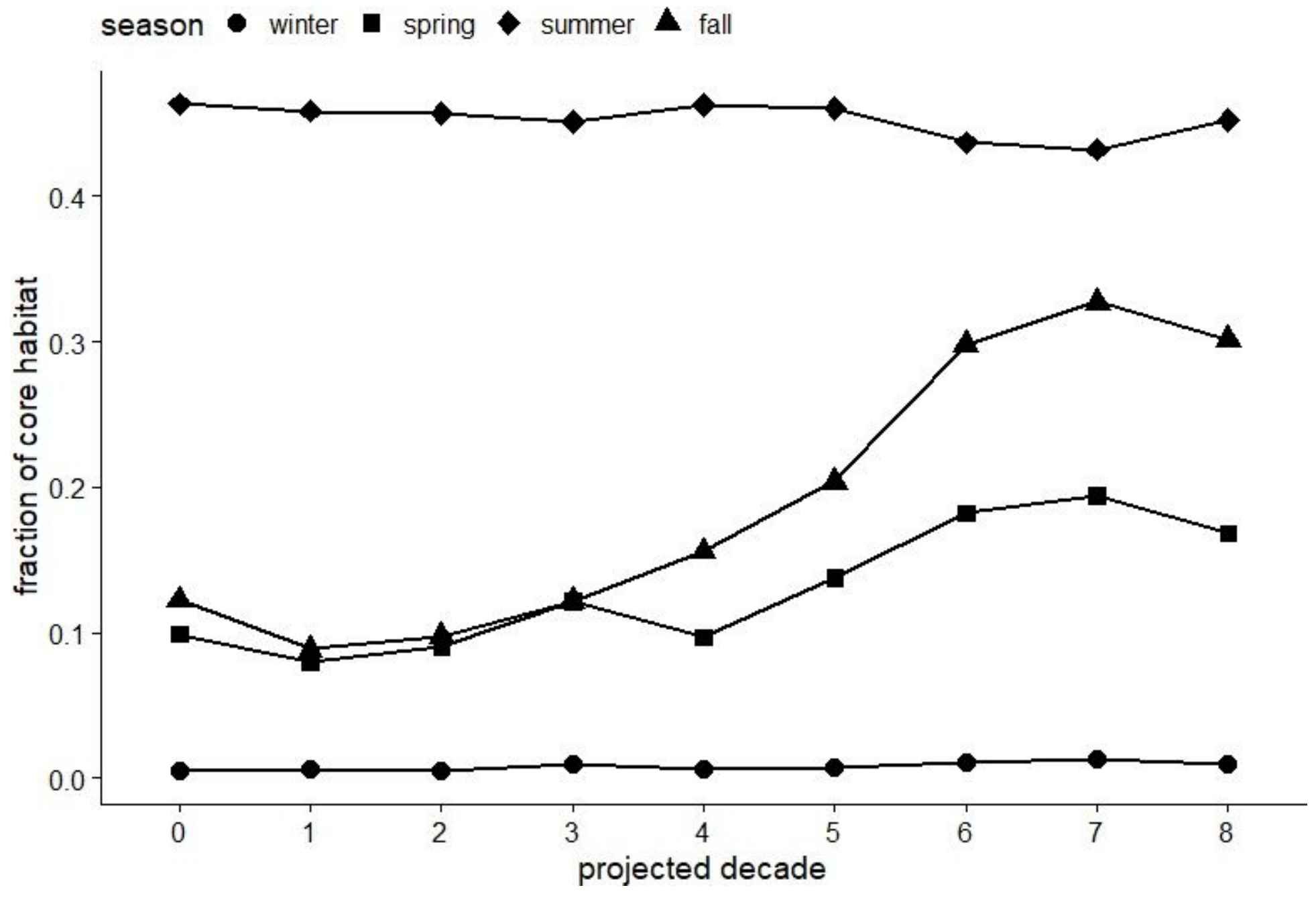

Figure 5

Change in fraction of th e NW Atlantic shelf region identified as core habitat for loggerheads across the projected 80 years binned by decade. Spring and fall are projected to have the largest change. Decade ' 0 ' refers to the observed data. 